INSTITUTE OF FORESTRY • BELGRADE

INSTITUT ZA ŠUMARSTVO • BEOGRAD

SUSTAINABLE FORESTRY

COLLECTION 69-70, 2014
ODRŽIVO ŠUMARSTVO

ZBORNIK RADOVA 69-70, 2014

UDK 630*232.12:630*174.75 Pseudotsuga menziesii (Mirb.) Franco=111

Original scientific paper

\title{
THE PHOSPHORUS ANALYZES IN NEEDLES OF CANADIAN DOUGLAS-FIR PROVENANCES
}

\author{
Vera LAVADINOVIC' ${ }^{1}$, Zoran MILETIĆ ${ }^{l}$, Vukan LAVADINOVIĆ
}

\begin{abstract}
Douglas-fir (Pseudotsuga menziesii Mir / Franco) is an indigenous and economically the most widespread species of conifers in Canada and North America. It is also the most common introduced species conifer in Europe.

In Serbia testing of Douglas-fir, began setting up several provenance plots with seeds originating from Canada and North America. The research work carried out at the Institute of Forestry, conducting analysis in order to select the most adaptive and productive provenances for reforestation in Serbia. The seeds transfer of introduced species of trees include testing of all characteristic by provenance test. Genetic feature of trees species show in the new environmental, to confirm the selection of tree type for introduction. One of the methods of assessing the genetic variability of introduced species is the testing using provenance experiment.

The intensity effect of physiological processes of mineral nutrition of tree species is one of the most important indicators of its successful adaptation and production into new environment habitats.

This research analyzes the phosphorus content in the needles of Douglas-fir from different provenances originating from Canada.
\end{abstract}

Key words: Douglas-fir, seed transfer, provenances, phosphorus, needles,

\section{ANALIZA FOSFORA U ČETINAMA DUGLAZIJE KANADSKIH PROVENIJENCIJA}

Apstrakt: Duglazija (Pseudotsuga menziesii Mir / Franco) je autohtona najrasprostranjenija i ekonomski najvažnija vrsta četinara u Kanadi i Severnoj Americi.

\footnotetext{
${ }^{1}$ Institute of Forestry, Belgrade,

${ }^{2}$ Faculty of Forestry, Belgrade, Serbia

Email: veralava@eunet.rs
} 
Takođe je najčešća introdukovana vrsta četinara u Evropi. U Srbiji istraživanje na duglaziji, počelo je postavljanjem nekoliko provenijeničnih testova sa semenom poreklom iz Kanade i Severne Amerike. Istraživački rad odvija se u Institutu za šumarstvo, sprovođenjem analiza kako bi se odabrale najvažnije adaptivne $i$ produktivne provenijencije za pošumljavanja u Srbiji. Transfer semena introdukovanih vrsta drveća uključuju ispitivanje svih karakteristika metodom provenijeničnog testa. Genetska karakteristika stabala vrste, $u$ novim životnim sredinama, treba da potvrdite selekciju stabla za introdukciju. Jedan od metoda procenu genetičke varijabilnosti uvedenih vrsta je testiranje pomoću provenijeničnog eksperimenta.

Efekat intenziteta fizioloških procesa mineralne ishrane vrsta drveća je jedan od najvažnijih pokazatelja njene uspešne adaptacije $i$ proizvodnosti u nove životne sredine staništa.

Ovo istraživanje analizira sadržaj fosfora u četinama duglazije iz različitih provenijencija poreklom iz Kanade.

Ključne reči: duglazija, transfer semena, provenijencija, fosfor, četine

\section{INTRODUCTION}

Nutrient supply is one of the most important criteria when describing the condition of conifers and needle analyses are an efficient method of evaluating the nutrient situation of conifer stands (K. Stefan, F. Herman 1996).

The obstacles that introduced species must be overcome is survival in the new habitat. That means the typical environmental barriers are such as: seed germination, soil $\mathrm{pH}$ and nutrient availability.

The seeds transfer of introduced species of trees include testing of all characteristic by provenance test. Genetic feature of trees species show in the new environmental, to confirm the selection of tree type for introduction.One of the methods of assessing the genetic variability of introduced species is the testing using provenance experiment.

The process of introduction is justified only if the introduced species are better or at least the same potential as the native tree species.

Douglas-fir (Pseudotsuga menziesii Mir / Franco) is one of the most ecologically and economically important trees in western North America, and is planted as an exotic timber species in Europe, New Zealand, Australia and Chile. It has one of the widest natural ranges of any tree species, extending from the Pacific Coast to the eastern slope of the Rocky Mountains and from $19^{\circ} \mathrm{N}$ in Mexico to $55^{\circ} \mathrm{N}$ in western Canada (Hermann, R.K. 1987, Hermann and Lavender, 1990, Rehfeldt GE. 1979, 1982, 1983, 1989;).

Douglas-fir is Canada's largest conifer and the tree that first made British Columbia famous as a producer of exceptionally fine timber. It is found throughout the southern half of the province extending into south-western Alberta. The species reaches its northern limit near the Queen Charlotte Islands. It grows to its magnificent best on the coast in fairly deep, moist sites where it comprises about $10 \%$ of the forest. (Website: www.coastforest.org).

The introduction of exotic species is considered one of the most important supplement to the native ecosystem: contributing to the diversity and improve the productivity of wood mass. It's one of the reasons that in Serbia started researching 
Douglas -fir as a very promising species of conifers. (Lavadinović, V., Koprivica, M. 1996 a, 2000, Lavadinović 2000, Lavadinović et al 2011)

The primary proces of phosphorous in the physiological processes in trees is the transfer of energy and regulation of metabolic processes, such as photosynthesis, synthesis of the primary and secondary chemical compounds (hydrocarbons, lipids, proteins, nucleic acids, etc).

This element enters phospholipids, which are the necessary components of membrane components in the cell, nucleic acids (RNA and DNA) and nucleoproteins Sarić, M. (1979):. Phosphorous enters phytic acid, the compound which most frequently occurs in seed. The phosphorous from phytic acid transforms during germination and incorporates into different compounds needed for the metabolism of young plants (Đukić M., Isajev, V.1991). It affects them indirectly, by stimulating the development of soil microorganisms, thereby accelerating the mineralization of the nutrients in the soil. Since this element is important for the numerous constituent and functional roles in the life processes of plants, the variability of quantitative and qualitative phosphorous content in plant organisms is used in plant breeding, as the indicator of the inter-individual and population variability (Mika, P.G et al., 1990).

\section{MATERIALS AND METHODS}

Douglas- Fir seed was collected from the part of natural range in Canada. Collection of seeds from 14 provenances were imported by Canadian Forest Service. Table 1 presents the characteristics of geographic data provenance of Douglas-fir.

In the Institute of Forestry nursery, from the seed it was produced seedlings from which it where formed two experimental plots.

Table 1. Geographical characteristics of the tested Douglas-fir provenances

\begin{tabular}{|c|c|c|c|c|c|c|}
\hline \multicolumn{2}{|c|}{ Provenance } & \multirow[t]{2}{*}{ Seed zone } & \multirow[t]{2}{*}{ Location } & \multirow[t]{2}{*}{ Latitude } & \multirow[t]{2}{*}{ Longitude } & \multirow[t]{2}{*}{ Altitude } \\
\hline No. & Code & & & & & \\
\hline 1 & 03333 & East Kootenay & Cranbrook & $49^{0} 25^{\prime}$ & $115^{0} 20^{\prime}$ & $1050 \mathrm{~m}$ \\
\hline 2 & 00848 & West Kootenay & Inonoaklin & $49^{0} 50^{\prime}$ & $118^{0} 10^{\prime}$ & $671 \mathrm{~m}$ \\
\hline 3 & 30667 & Shuswap Adams & Mann Creek & $51^{0} 35^{\prime}$ & $120^{0} 10^{\prime}$ & $600 \mathrm{~m}$ \\
\hline 4 & 05227 & East Kootenay & Gavia Lake tfl 14 & $50^{0} 56^{\prime}$ & $116^{0} 35^{\prime}$ & $1070 \mathrm{~m}$ \\
\hline 5 & 05226 & East Kootenay & Nine Bay TFL 14 & $50^{\circ} 58^{\prime}$ & $116^{0} 32^{\prime}$ & $975 \mathrm{~m}$ \\
\hline 6 & 03356 & Thompson Okanagan Arid & Trout $\mathrm{Cr}$ & $49^{0} 40^{\prime}$ & $119^{0} 52^{\prime}$ & $884 \mathrm{~m}$ \\
\hline 7 & 03360 & Thompson Okanagan Arid & Michell Cr & $49^{0} 54^{\prime}$ & $119^{0} 37^{\prime}$ & $1035 \mathrm{~m}$ \\
\hline 8 & 01198 & West Kootenay & Salmo & $49^{0} 15^{\prime}$ & $117^{0} 30^{\prime}$ & $793 \mathrm{~m}$ \\
\hline 9 & 30460 & Shuswap Adams & Mara LK & $50^{\circ} 48^{\prime}$ & $119^{0} 00^{\prime}$ & $488 \mathrm{~m}$ \\
\hline 10 & 00278 & Thompson Okanagan Arid & Monte Crk & $50^{0} 37^{\prime}$ & $119^{0} 52^{\prime}$ & $701 \mathrm{~m}$ \\
\hline 11 & 03383 & West Kootenay & Sheep Creek & $49^{0} 10^{\prime}$ & $117^{0} 15^{\prime}$ & $1000 \mathrm{~m}$ \\
\hline 12 & 30461 & Shuswap Adams & Cooke Creek & $50^{0} 38^{\prime}$ & $118^{0} 49^{\prime}$ & $900 \mathrm{~m}$ \\
\hline 13 & 03389 & West Kootenay & Benton Creek & $49^{0} 12^{\prime}$ & $117^{0} 25^{\prime}$ & $933 \mathrm{~m}$ \\
\hline 14 & 05092 & East Kootenay & Sun Creek & $50^{\circ} 08^{\prime}$ & $115^{0} 52^{\prime}$ & $1000 \mathrm{~m}$ \\
\hline
\end{tabular}

Soil at one site, where the experimental provenance plots set, is the eutric cambisol, and the second plot it is vertisol. All plants of Douglas- fir were reared under identical site and identical stand conditions, and age of all the analyzed individuals are 12 years. 
Both sites, where they placed the trials were flattened surface, without significant exposure and altitude are about the same.

For the determination of phosphorus in the soil at both sites were sampled taken needles of light from the upper third of the crown of Douglas -fir trees. Phosphorus content in the needles of Douglas -fir where determined by analysis of the ash after dry ashing at a temperature of $550^{\circ} \mathrm{C}$ and the translation of nutrition elements in chlorides. Determination was carried out by colorimetric method

Needles to determine the state of nutrition of Douglas- fir were collected during dormancy from the upper third of the tree canopy. Phosphorus content in the needles of Douglas -fir determined by analyzing the ash after burning dry colorimetric method. Linear regression analysis examined the effect of nutrition with phosphorus on the state of growth elements (mean diameter, mean height, basal area, volume and increment) studied provenances of Douglas fir. The amount of phosphorus available plants in the soil was determined with AL- method by Egner-Rihm (Džamić et al 1966).

\section{RESULTS AND DISCUSSION}

Based on the conducted studies, it can be concluded that conditions of phosphorous nutrition on eutric cambisol are considerably more favourable than the ones on vertisol. The difference in phosporous nutrition is significant at $p<$ 0.01. Nearly all Douglas-fir provenances cultivated on eutric cambisol had better phosphorous nutrition in comparison to the provenances cultivated on vertisol (Table 2, Graph 1). The exceptions are the Gavia Lake locality provenance, the East Kootenay seed zone, the code 05227, and the Salmo locality provenance, the West Kootenay seed zone, the code 01198. In both provenances cultivated on vertisol, slightly higher amounts of phosphorous were identified in comparison to the same provenances cultivated on eutric cambisol.

Tabela 2. The content of calcium on different provenances in Douglas - fir needles

\begin{tabular}{|c|c|c|c|c|c|c|}
\hline \multirow{3}{*}{ No } & \multirow{3}{*}{ Code } & \multirow{3}{*}{ Locality } & \multicolumn{2}{|c|}{ Vertisol } & \multicolumn{2}{|c|}{ Cambisol Eutric } \\
\hline & & & $\mathrm{P}$ & \multirow{2}{*}{$Z$} & $P$ & \multirow{2}{*}{ Z } \\
\hline & & & $\%$ & & $\%$ & \\
\hline 1 & 03333 & Cranbrook & 0.236 & -0.299 & 0.245 & -0.572 \\
\hline 2 & 00848 & Inonoaklin & 0.237 & -0.342 & 0.258 & -0.986 \\
\hline 3 & 30667 & Mann Creek & 0.209 & 0.546 & 0.267 & -1.283 \\
\hline 4 & 05227 & Gavia Lake & 0.216 & 0.344 & 0.213 & 0.423 \\
\hline 5 & 05226 & Nine Bay & 0.222 & 0.134 & 0.246 & -0.600 \\
\hline 6 & 03356 & Trout Creek & 0.189 & 1.183 & 0.249 & -0.715 \\
\hline 7 & 03360 & Michell Creek & 0.206 & 0.662 & 0.272 & -1.438 \\
\hline 8 & 01198 & Salmo & 0.228 & -0.050 & 0.206 & 0.654 \\
\hline 9 & 30460 & Mara Lake & 0.215 & 0.353 & 0.257 & -0.974 \\
\hline 10 & 00278 & Monte Creek & 0.195 & 1.005 & 0.204 & 0.702 \\
\hline 11 & 03383 & Sheep Creek & 0.165 & 1.939 & 0.221 & 0.175 \\
\hline 12 & 30461 & Cooke Creek & 0.228 & -0.048 & 0.257 & -0.956 \\
\hline 13 & 03389 & Benton Creek & 0.182 & 1.405 & 0.249 & -0.692 \\
\hline
\end{tabular}




\begin{tabular}{|c|c|c|c|c|c|}
\hline 05092 & Sun Creek & 0.172 & 1.732 & 0.299 & -2.301 \\
\hline & Average & & 0.207 & & 0.246 \\
\hline & $\mathrm{S}$ & & 0.02341 & & 0.02694 \\
\hline & $\min$ & & 0,165 & & 0.204 \\
\hline & $\max$ & & 0.237 & & 0.299 \\
\hline & T-value & 4.074882 & & & \\
\hline & P-Value & \multicolumn{4}{|c|}{0.000192 The result is significant at $\mathrm{p}<0.01$} \\
\hline \multirow{4}{*}{ For both populations } & Average & \multicolumn{4}{|r|}{0227} \\
\hline & $\mathrm{S}$ & \multicolumn{4}{|r|}{0.03166} \\
\hline & $\min$ & \multicolumn{4}{|r|}{0.165} \\
\hline & $\max$ & \multicolumn{4}{|r|}{0.299} \\
\hline
\end{tabular}

Although all seedlings at both sites reared under identical site and stand conditions, the same type of soil and climate under identical conditions was found high variability among provenances of phosphorus content in the needles in both provenances were grown on eutric cambisol, and with provenance grown on vertisols.

All conditions that affect physiological processes in plants, and thus the adoption of nutrients from the soil were identical for all provenances, both at the site where the soil is vertisol, and at the site where the soil is Eutric cambisol. Therefore, the variability of phosphorus content in the needles of different provenances consequences of genetically inherited abilities of different provenances to exploit the potential of soil and achieve phosphorus nutrition.

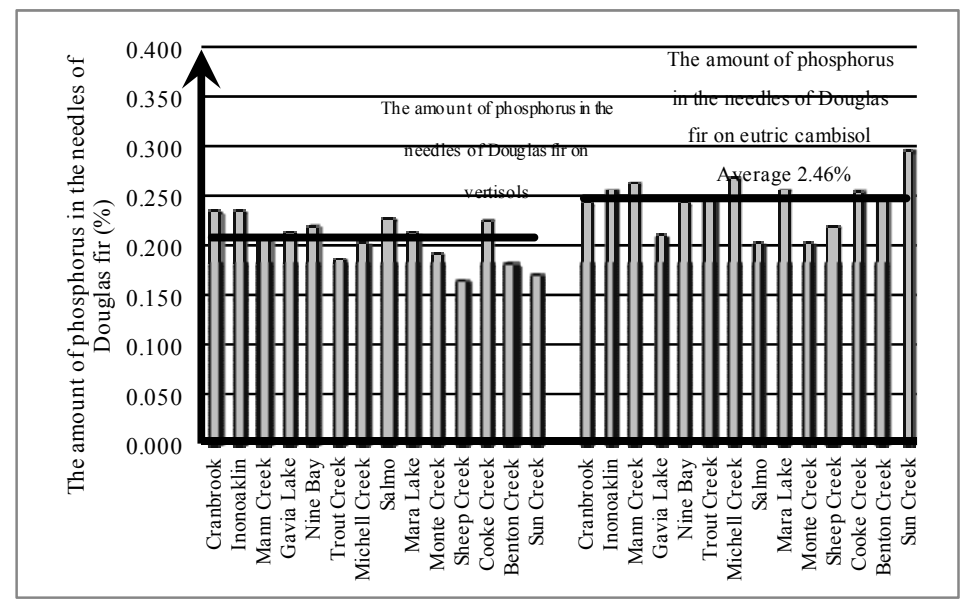

Figure 1. The amount of phosphorus in the needles of Douglas-fir on vertisol and eutric cambisol

The inter-provenance variability of phosphorus content in Douglas-fir needles is presented in Table 2 and Graph 2. The highest percentage representation of phosphorus in needles of Douglas-fir cultivated on vertisol $(0.237 \%)$ was identified in the Inonoaklin locality provenance, the West Kootenay seed zone, the 
code 00848 , while the lowest percentage representation $(0.165 \%)$ was determined in the Sheep Creek locality provenance, the West Kootenay seed zone, the code 03383.

Among the Douglas-fir provenances cultivated on eutric cambisol, the highest content of phosphorus was identified in the Douglas-fir needles of the Sun Creek locality provenance, the East Kootenay seed zone, the code 05092. The lowest representation of phosphorus in needles of Douglas-fir cultivated on eutric cambisol was identified in the Monte Creek locality provenance, the Thompson Okanagan Arid seed zone, the code 00278.

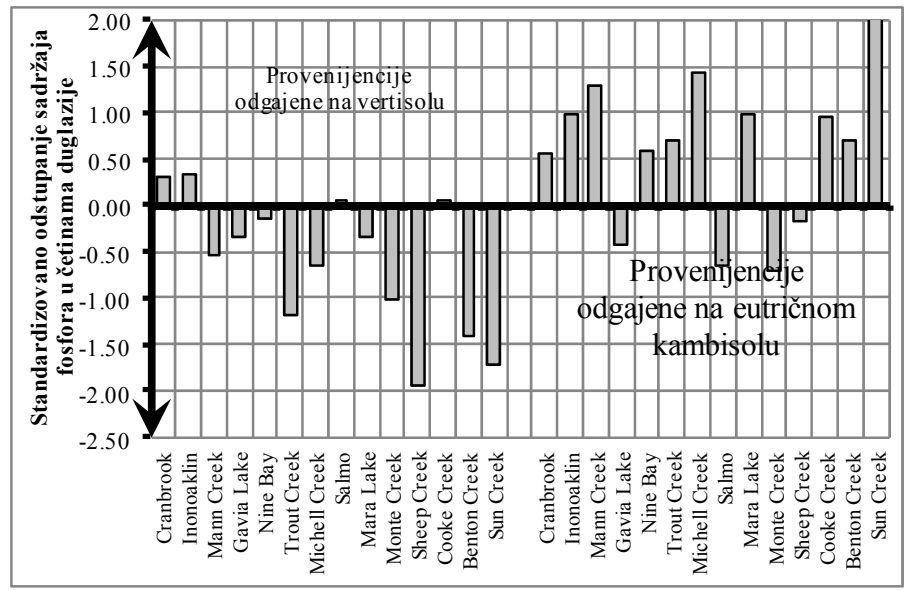

Figure 2. Standardized deviation of phosphorus content in the needles of Douglasfir provenances

\section{CONCLUSION}

Based on the results of conducted analyses of phosphorus nutrition conditions in 14 Douglas-fir provenances of Canadian origin, it can be concluded that eutric cambisol provides far more favourable conditions for phosphorus nutrition than vertisol. Nearly all provenances cultivated on eutric cambisol assimilated a higher amount of phosphorus in comparison to the same provenances cultivated on vertisol.

Given the uniformity of conditions for soil nutrient assimilation in both provenance trial localities, it can be concluded that there are genetic specificities relating to calcium assimilation process. The inter-provenance variability of calcium content in Douglas-fir needles is an indicator of genetic pool specificity of different provenances with respect to calcium nutrition.

Based on the conducted study, it can be concluded that phosphorus content differences in Douglas-fir needles point out to a variability in the intensity of physiological processes in genotypes of different provenances. Given the fact that the Douglas-fir trees grew and developed in relatively small areas, with uniform general site and stand conditions, it can be concluded that needle phosphorus amounts are determined by different genotypes that constitute the genetic pool of studied Douglas-fir provenances. 


\section{REFERENCES}

Đukić M., Isajev, V.(1991):Varijabilnost sadržaja azota kalijuma, fosfora i belančevina u četinama jednogodišnjih sadnica smrče iz osam provenijencija. Glasnik Šumarskog fakulteta br. 73.Beograd: 319-325

Džamić, R., Stevanovć, D., Jakovjević, M. (1996): Praktikum iz agrohemije, Poljoprivredn fakultet, Beograd - Zemun.

K. Stefan, F. Herman (1996): Nutrient Contents of Spruce Needles from theTyrolean Limestone Alps. Phyton (Horn, Austria) Special issue:"Achenkirch II" Vol.36.Fasc 4. Pp 231-244

Lavadinović, V., Koprivica, M. (1996 a): Tracheid width of different Douglas fir (Pseudotsuga taxifolia Britt.) Provenances in test plantations in the region of Serbia. Proceedings of the 2nd International Conference on the Development of Wood Science Technology and Forestry, Sopron, Hungary: 277-286

Lavadinović, V., Koprivica, M. (2000): Douglas-fir Provenance Test in Serbia. Vol. 3, XXI IUFRO World Congress, 7-12 August 2000, Kuala Lumpur, Malaysia: 81

Lavadinović, V. (2009): Genetic and ecological variabilities of Douglas fir (Pseudotsuga menziesii /Mirb./ Franco) in provenance experiments in Serbia. Ph.D. Thesis, The Faculty of Forestry, Belgrade

Lavadinović,V., Miletić,Z., Isajev,V., Rakonjac,Lj., Lučić,A. (2011): Variability of Phosphorus Content in Needles of Different Douglas-Fir Provenances. Proceedings of the Biennial International Symposium Forest and Sustainable Development. "Transilvania" University of Brasov ISSN 1843-505X. Faculty of Silviculture and Forest Engineering. Brashov 15-16.October,2010 Romania. P 47-52

Mika, P.G., Vander Ploeg, J. (1990): Six Year Fertilizer Response of Managed SecondGrowth Douglas-fir Stands in the Inlands Northwest. Symposium Proceedings of Interior Douglas-fir - the species and its management, Washington, USA: 293-301

Sarić, M. (1979): Fiziologija biljaka. Univerzitet u Novom Sadu. Naučna knjiga, Beograd

Hermann, R.K. (1987): North American tree species in Europe. Journal of Forestry,85:2732.

Hermann RK, Lavender DP. 1990.Pseudotsuga menziesii (Mirb.) Franco Douglas fir. In: Burnes RM, Honkala BH, eds. Silvics of North America. Volume 1. Conifers. Agriculture Handbook 654. Washington, DC: US Department of Agriculture, Forest Service, 527-540.

Rehfeldt GE. 1979. Ecological adaptations in Douglas fir (Pseudotsuga menziesii var. glauca) populations. I. North Idaho and north-east Washington. Heredity 43: 383-397.

Rehfeldt GE. 1982. Ecological adaptations in Douglas fir populations. II. Western Montana. Research Paper INT-295. Ogden, UT: US Department of Agriculture, Forest Service, Intermountain Forest and Range Experiment Station, 8 pp.

Rehfeldt GE. 1983. Ecological adaptations in Douglas fir (Pseudotsuga menziesii var. glauca) populations. III. Central Idaho. Canadian Journal of Forest Research 13: 626-632.

Rehfeldt GE. 1989. Ecological adaptations in Douglas fir (Pseudotsuga menziesii var. glauca): a synthesis. Forest Ecology and Management 28: 203-215. 
Weber, E. (2003): Invasive plant species of the world: a reference guide to environmental weeds. Geobotanical Institute, Zurich, Switzerland. 357 p.

Williams, C. E. (1997): Potential valuable ecological functions of nonindigenous plants. In Luken, U.O. and J. W. Thieret (eds.). Assessment and management of plant invasions. Springer-Verlag, New York, NY, p. 26-34.

Website: www.coastforest.org .Coast Forest production publication (2003): Douglas- fir British Columbia's famous fir. Canada Wood Produits boise canadien. Forestry Innovatiom Investment.Ltd. Coast Region of British Columbia.

\title{
PHOSPHORUS ANALYZES IN NEEDLES OF CANADIAN DOUGLAS-FIR PROVENANCES
}

\author{
Vera LAVADINOVIĆ, Zoran MILETIĆ, Vukan LAVADINOVIĆ
}

\section{Summary}

Among the provenance variability of phosphorus content in the needles of 14 Douglas-fir, from Canada, is presented in this research. Douglas-fir is an indigenous and economically the most widespread species of conifers in Canada and North America. It is also the most common introduced species conifer in Europe. The seeds transfer of introduced species of trees include testing of all characteristic by provenance test. Genetic feature of trees species show in the new environmental, to confirm the selection of tree type for introduction.One of the methods of assessing the genetic variability of introduced species is the testing using provenance experiment. Based on the results of conducted analyses of phosphorus nutrition conditions in 14 Douglas-fir provenances of Canadian origin, it can be concluded that eutric cambisol provides far more favourable conditions for phosphorus nutrition than vertisol. Nearly all provenances cultivated on eutric cambisol assimilated a higher amount of phosphorus in comparison to the same provenances cultivated on vertisol.

\section{ANALIZA FOSFORA U ČETINAMA DUGLAZIJE KANADSKIH PROVENIJENCIJA}

\author{
Vera LAVADINOVIĆ, Zoran MILETIĆ, Vukan LAVADINOVIĆ
}

\section{Rezime}

Međuprovenijenična varijabilnost sadržaja fosfora $u$ četinama duglazije predstavljena je u ovom istraživanju. Duglazija je autohtona najrasprostranjenija i ekonomski najvažnija vrsta četinara u Kanadi i Severnoj Americi. Takođe je najčešća introdukovana vrsta četinara u Evropi. Transfer semena introdukovanih vrsta drveća uključuju ispitivanje svih karakteristika metodom provenijeničnog testa. Genetska karakteristika stabala vrste, u novim životnim sredinama, treba da potvrdite selekciju stabla za introdukciju. Jedan od metoda procenu genetičke varijabilnosti uvedenih vrsta je testiranje pomoću provenijeničnog eksperimenta. $\mathrm{Na}$ osnovu rezultata obavljenih analiza stanja ishrane fosforom 14 provenijencija duglazije poreklom iz Kanade može se konstatovati da eutrični kambisol obezbeđuje daleko povoljnije uslove za ishranu ovim elementom u odnosu na vertisol. Skoro sve provenijencije odgajene na eutričnom kambisolu su usvojile veću količinu fosfora iz zemljišta u odnosu na iste provenijencije odgajene na vertisolu. 